\title{
Halau Jerebu Asap: Kebijakan dan Gerakan Pro-Keadilan Lingkungan
}

\author{
Hotmauli Sidabalok \\ oely.sidabalok@unika.ac.id \\ Universitas Katolik Soegijapranata, Semarang
}

\begin{abstract}
The forest fires in Indonesia already become the chronical annual issue. Beside the climate change, there are some influence factors for this issue. First is the unequal policy which stands for the oil plantation industry. Second is government has multi interpretation to consider this issue as a disaster. Third is the weakness of stakeholders to protect forest and environment. Those three factors are analysed by using the environmental justice and the movement to protect environmental concepts. This article describes some causal factors to environmental injustice on smog disaster, the efforts to minimize disaster and environmental justice movement. The movement does not only to protect human being but also the environment. The experience and awareness to the smog become the momentum for the environmental justice movement in Indonesia.
\end{abstract}

Keywords: The smog, environmental justice, and environmental justice movement

ABSTRAK: Kebakaran hutan di Indonesia telah menjadi masalah menahun yang berulang kambuh bak penyakit kronis. Selain perubahan iklim, ada beberapa faktor yang mempengaruhi tidak tuntasnya masalah ini. Kebijakan pemerintah yang berpihak pada sekelompok orang menjadi faktor pertama, diikuti multitafsir pemerintah yang mengganggap kondisi ini sebagai bencana dan lemahnya kesadaran pemangku kepentingan terhadap upaya perlindungan hutan dan lingkungan. Ketiga faktor ini akan dianalisis dengan menggunakan konsep keadilan lingkungan dan gerakan perlindungan lingkungan. Tulisan ini memaparkan berbagai penyebab ketidakadilan lingkungan bencana kabut asap, upayaupaya meminimalkan bencana serupa di masa mendatang serta gerakan keadilan lingkungan yang tidak hanya memberi perlindungan pada manusia tetapi juga perlindungan terhadap lingkungan. Pengalaman dan kesadaran terhadap bencana kabut asap di negeri ini, seharusnya menjadi momentum memunculkan gerakan lingkungan. Tujuannya adalah untuk menyelamatkan manusia dan hutan dengan mempengaruhi berbagai kebijakan pemerintah yang selama ini sangat berpihak pada industri dan perkebunan kelapa sawit.

Kata-kata kunci: kebakaran hutan, keadilan lingkungan dan gerakan perlindungan

\section{PENDAHULUAN}

\section{LATAR BELAKANG}

Kebakaran hutan di negeri ini tidak sepenuhnya berhenti meskipun upaya Pemerintah Pusat dan Daerah tak kurang-kurang untuk mengatasinya. Pada bulan Maret lalu, media nasional (Kompas, 16/03/2020) mengabarkan kesatuan polisi berjibaku mengatasi kebakaran hutan di wilayah Indragiri Hilir, Riau. Namun berita ini menjadi tidak penting karena pada waktu yang hampir bersamaan, ada isu pandemi virus baru korona yang menyedot perhatian Pemerintah Indonesia. Kondisi ini semakin diperparah dengan musim panas yang cukup 
panjang akibat perubahan iklim. Kebakaran hutan berkepanjangan di Indonesia tidak saja penting menjadi catatan perbaikan kebijakan perlindungan hutan, namun seharusnya menjadi entry point dalam mengatasi berbagai ketidakadilan lingkungan yang muncul. Harapannya kondisi ini memberi pelajaran bagi pemerintah untuk melahirkan kebijakan yang resiko yang tidak adil dalam pemanfaatan hutan dan memberikan ruang bagi gerakan perlindungan lingkungan yang sehat dan baik. Tulisan ini memaparkan berbagai penyebab ketidakadilan lingkungan bencana kabut asap, upaya-upaya meminimalkan bencana serupa di masa mendatang serta gerakan keadilan lingkungan yang tidak hanya memberi perlindungan pada manusia tetapi juga perlindungan terhadap lingkungan.

\section{PEMBAHASAN}

\section{Kebijakan Sawit Anak Emas Pemerintah yang Membawa Bencana}

Berdasarkan catatan Direktorat Jenderal Penegakan Hukum Lingkungan Hidup dan Kehutanan Kementerian Lingkungan Hidup dan Kehutanan tahun 2015 (Kompas, 15/09/2015) ada kurang lebih 10 perusahaan kelapa sawit melakukan pembakaran lahan di 4 provinsi (Riau, Sumatera Selatan, Jambi dan Kalimantan Tengah). Kelapa sawit adalah salah satu komoditi primadona penghasil devisa Indonesia terbesar. Pada 2014 saja tercatat ada 4,2 milyar US Dollar nilai ekspor crude palm oil (CPO). Cerahnya prospek komoditi CPO dalam perdagangan minyak nabati dunia mendorong Pemerintah memberikan kemudahan dalam pengembangan perkebunan kelapa sawit. Pemerintah memberikan berbagai insentif, perijinan dan bantuan subsidi investasi untuk pembangunan perkebunan inti rakyat (PIR) dan perkebunan swasta. Bahkan dengan prinsip otomomi daerah, Pemerintah Kabupaten Kotawaringin Timur mencanangkan program "Lahan Sawit Sejuta Hektar” pada tahun 2013.

Berbagai kebijakan ini secara langsung berimbas pada masifnya pembukaan lahan baru untuk perkebunan kelapa sawit. Bahkan rawa gambut yang fungsinya sebagai ekosistem penangkap air, dengan berbagai cara diubah menjadi lahan baru bagi perkebunan sawit yang dianggap lebih menguntungkan secara ekonomi dan memberikan devisa pada negara. Kebijakan "proyek lahan gambut sejuta hektar" pada dua dekade lalu telah tercatat menjadi sejarah perusakan lingkungan masif terhadap rawa gambut. Rawa gambut dikeringkan untuk tujuan penambahan lahan bagi hutan tanaman industri termasuk sawit. Berdasarkan catatan Badan Pusat Statistik (BPS, 2014), pada tahun 2014 ada seluas 6.404.000 hektar areal perkebunan besar dan 4.551.850 hektar perkebunan rakyat yang ditanami kelapa sawit. Jumlah ini meningkat rata-rata 1 juta hektar setiap lima tahun sejak tahun 2000.

Keuntungan yang menggiurkan dari industri kelapa sawit menyebabkan pembukaan dan perluasan lahan perkebunan sawit cenderung dilakukan dengan cara-cara mudah dan murah tanpa mempertimbangkan resiko lingkungan seperti halnya perambahan, pembalakan, pengeringan rawa gambut dan pembakaran hutan. Dalam tahun 2014-2015 saja ada sekitar 30 persen hutan dan kawasan konservasi (seluas 10,5 juta hektar) rusak karena perilaku tidak bertanggung jawab pelaku pembakaran lahan (Kompas 14/09/2015).

Kebijakan yang berpihak pada perkebunan sawit ini secara perlahan menjadi salah satu pemicu Indonesia kehilangan hutan paling luas di peringkat kedua setelah Brazil. Sejak 2010 Indonesia sudah kehilangan hutan rata-rata 684.000 hektar per tahun (FAO-UN, Global Forrest Resource Assessment, 2015). Anak emas ini secara perlahan berubah menjadi anak mbalelo bagi orangtuanya sendiri yaitu Pemerintah Indonesia. 


\section{Gagal Paham Konsep ‘Bencana’ Kebakaran Hutan}

Selain kebijakan pemerintah yang berpihak pada investor sebagaimana dijelaskan di atas, berlarut-larutnya penanganan kebakaran lahan di negeri ini disebabkan pula oleh perbedaan cara pandang dalam memahami konsep bencana. Ironisnya lagi, beberapa pihak beranggapan -dan mungkin telah diadopsi menjadi dasar kebijakan- bahwa; "pernyataan kebakaran hutan sebagai bencana akan meloloskan pelaku pembakaran lahan dari jerat hukum" atau "kebakaran hutan belum perlu menjadi bencana nasional karena hanya terjadi di beberapa wilayah republik saja yaitu; Pulau Sumatera, Kalimantan dan Papua dan tidak meluas secara nasional. Dua argumentasi dangkal ini bahkan telah mengabaikan bertambahnya jumlah korban meninggal contohnya pada tahun 2015 yaitu (12 orang), 40 juta jiwa jumlah korban terdampak dan terampas haknya atas udara yang sehat dan baik (Kompas 13 November 2015), kerugian materiil, hilangnya sumber daya alam hutan dan menurunnya kualitas lingkungan. Tidak heran, gagal paham konsep bencana ini berelasi dengan kegagalan manajemen resiko kebakaran hutan Indonesia secara berulang sejak 17 tahun lalu.

"Apa toh bedanya sebuah peristiwa dinyatakan sebagai bencana atau kejadian biasa"? Ternyata penggunaan konsep resmi 'bencana' akan berimplikasi pada penyelenggaraan penanggulangan bencana; mulai kebijakan pra bencana, tanggap darurat dan pasca bencana; sumber daya yang terlibat; sampai pada sumber biaya yang akan digunakan. Sementara dalam kaca mata awam seringkali tanggap darurat hanya digunakan untuk mengukur kepedulian dan tanggung jawab negara dalam menjamin keamanan dan kesehatan publik.

Konsep bencana, berdasarkan Pasal 1 (1) Undang-Undang No. 24 Tahun 2007 Tentang Penanggulangan Bencana, adalah "peristiwa atau rangkaian peristiwa yang mengancam dan mengganggu kehidupan dan penghidupan masyarakat yang disebabkan, baik oleh faktor alam dan/atau faktor non-alam maupun faktor manusia sehingga mengakibatkan timbulnya korban jiwa, kerusakan lingkungan, kerugian harta benda, dan dampak psikologis". Unsur penting bencana dalam konteks ini adalah; akibat yang mengancam kehidupan dan keberlangsungan kehidupan masyarakat.

Dalam penjelasan umum Undang-Undang tersebut, potensi penyebab bencana dikelompokkan dalam 3 hal yaitu; bencana alam, non-alam, dan sosial. Bencana alam dengan mudah dapat ditandai dengan peristiwa yang disebabkan oleh alam misalnya gempa bumi, letusan gunung berapi, angin topan, tanah longsor, kekeringan, kebakaran hutan/ lahan karena faktor alam, hama penyakit tanaman, epidemi, wabah, kejadian luar biasa, dan kejadian antariksa/benda-benda angkasa. Sementara bencana non-alam dicontohkan dengan kebakaran hutan/lahan yang disebabkan oleh manusia, kecelakan transportasi, kegagalan konstruksi/teknologi, dampak industri, ledakan nuklir, pencemaran lingkungan dan kegiatan keantariksaan.

Kebakaran hutan dapat diidentifikasi sebagai peristiwa disebabkan dua hal; yaitu karena ulah manusia, yang diperparah dengan fenomena El-Nino dan kemarau berkepanjangan yang menyebabkan kebakaran hutan semakin meluas. Tidak ada keraguan untuk menyatakan bahwa kebakaran hutan yang berlangsung adalah bencana baik alam sekaligus non-alam. Lalu apa sebabnya Pemerintah masih tetap tak menyatakan kebakaran hutan sebagai bencana?

Apabila premis-nya untuk menjerat hukum pelaku pembakaran, dapat diasumsikan bahwa pengambil kebijakan terjebak pada pemahaman yang keliru dengan mereduksi 
konsep bencana semata sebagai peristiwa yang semata-mata disebabkan oleh alam atau force major di luar kehendak manusia. Ada sindrom bahwa tanggung jawab penanggulangan bencana alam akan beralih dari negara bukan pelaku. Korban, pendamping hukum class action, bahkan aparat hukum menemukan kesulitan menentukan pihak mana yang bertanggung jawab menanggung akibat perdata, pidana dan administratif kebakaran hutan yang meluas. Pengalaman serupa terjadi pada kasus lumpur Lapindo Sidoarjo. Setelah dinyatakan sebagai bencana alam, PT. Lapindo Brantas tak sepenuhnya lagi dapat dimintai pertanggung jawaban lingkungan meskipun telah terbukti menjadi pen-trigger bencana lumpur yang merugikan masyarakat. Prinsip pencemar bertanggung jawab (polluter pays principle) tak menjadi dominan lagi dalam kasus ini.

Asumsi ini membuat batas tanggung jawab hukum lingkungan pelaku dan tanggung jawab pemerintah dalam manajemen penanggulangan bencana kebakaran lahan menjadi samar, meskipun sebetulnya lingkupnya ada pada dua aras yang berbeda. Tanggung jawab hukum lingkungan dapat dikenakan pada korporasi pengelola lahan dan pejabat yang melakukan penyalahgunaan ijin. Hal tersebut diatur dalam Undang-Undang No. 32 Tahun 2009 Tentang Pengelolaan dan Perlindungan Lingkungan Hidup. Sementara tanggung jawab negara berada dalam tataran penyelenggaraan penanggulangan bencana yang bertujuan untuk memberikan perlindungan kepada masyarakat dari ancaman bencana kebakaran lahan/hutan dimulai dari pengurangan risiko kebakaran lahan/hutan; perlindungan masyarakat dari dampak kabut asap; penjaminan pemenuhan hak masyarakat dan pengungsi yang terkena bencana secara adil dan sesuai dengan standar pelayanan minimum; pemulihan kondisi dari dampak kebakaran lahan/hutan; pengalokasian anggaran penanggulangan bencana dalam APBN yang memadai; sampai pada pengalokasian anggaran penanggulangan bencana dalam bentuk dana siap pakai.

Asumsi kedua lebih tidak masuk akal lagi. Dampak kebakaran hutan dianggap terbatas secara geografi di Pulau Sumatera, Kalimantan, dan terakhir Papua. Secara de facto kebakaran hutan memang terjadi di sana tetapi dampak kabut asap tidak terbatas di langit wilayah itu saja. Tak dapat disangkal dampaknya telah mencapai negara jiran. Korban tidak saja anak dan balita yang telah kehilangan nyawa akibat penyakit Inspeksi Saluran Napas Akut (ISPA), tapi korban terpapar lainnya dengan terabaikannya hak warga negara atas lingkungan hidup yang baik dan sehat yang mengancam kesehatan jutaan penduduk tiga pulau dan negara jiran. Dampak lain adalah hilangnya keanekaragaman hayati hutan tropis, lenyapnya tempat hidup dan sumber makanan flora dan fauna dan kerugian triliyunan rupiah rupiah di sektor perhubungan udara.

\section{Berbagai Elemen Ketidakadilan Lingkungan Kabut Asap}

Fakta kabut asap dengan faktor-faktor pemicu berbagai hal tersebut ternyata tidak sesederhana persoalan hukum dengan tertangkap dan diadilinya pelaku pembakaran lahan. Kabut asap adalah fakta lingkungan yang telah memicu ketidakadilan lingkungan.

Ketidakadilan lingkungan akibat kabut asap, secara khusus digambarkan dalam beberapa elemen berikut (Walker, 2014: 40). Elemen pertama, dalam level normatif ada ketentuan perundang-undangan yang menjamin pemenuhan hak warna negara atas lingkungan hidup (dalam konteks ini adalah udara) yang baik dan sehat. Pasal $28 \mathrm{H}$ ayat 1 Amandemen UUD 1945 dan Pasal 64 Undang-Undang Lingkungan Hidup No. 32 Tahun 2009 dengan tegas mengatur bahwa setiap orang di republik ini berhak mendapatkan lingkungan hidup yang baik dan sehat. Ketentuan ini menjadi dasar menyatakan kondisi yang dialami korban meninggal dan korban terpapar kabut asap telah dilanggar hak lingkungannya. 
Elemen kedua adalah adanya bukti yang menguatkan pelanggaran hak atas lingkungan yang baik dan sehat di wilayah terpapar secara langsung maupun wilayah lainnya. Selama bencana kabut asap rata-rata kurang lebih hampir 4 bulan masyarakat di wilayah terpapar sulit menghirup udara yang sehat. Bahkan teridentifikasi terdapat kelompok rentan bayi dan anak-anak telah meninggal dan menderita ISPA. Konteks korban dalam ketidakadilan lingkungan tidak saja terbatas pada korban yang tidak terpenuhi haknya akan udara yang sehat dan bersih, atau korban yang mengalami kerugian materiil dan immaterial, namun juga rentan yang tidak berdaya seperti anak-anak dan orang lanjut usia. Banyak balita yang terpaksa mengalami serangan ISPA (infeksi saluran pernafasan) akibat kabut asap berkepanjangan. Mereka tidak sekuat korban orang dewasa yang masih mampu beradaptasi dengan minimnya udara sehat dan bersih. Bukti korban adalah elemen kuat yang menjadi tanda bahwa bencana kabut asap adalah kondisi yang bernuansa ketidakadilan lingkungan.

Sedangkan elemen ketiga adalah adanya kondisi yang menegaskan adanya distribusi resiko dan keuntungan yang tidak seimbang antara pelaku pembakaran lahan, industri sawit atau perkebunan lainnya dan masyarakat. Di satu sisi ada fakta bahwa perusahaan dan negara menerima keuntungan dan devisa dari perkebunan sawit, sedangkan di sisi lain ada korban yang harus menerima dampak dari pembakaran lahan untuk perkebunan sawit. Ada keuntungan dan resiko yang didistribusikan secara tidak seimbang antar pemerintah, pengusah dan masyarakat.

Bentuk ketidakadilan lain bahkan dapat dikelompokkan secara geografis. Masyarakat yang memiliki resiko paling besar tentulah masyarakat yang tinggal di wilayah terdampak. Pulau Sumatera dan Kalimantan dalam tata ruang wilayah Indonesia adalah tempat yang masih memungkinkan untuk perkebunan kelapa sawit karena pertimbangan ketersediaan lahan. Pertimbangan geografis pemilihan lokasi perkebunan ternyata secara tegas menunjukkan adanya perbedaan distribusi kualitas udara. Pulau Kalimantan dan Sumatera (beberapa tahun ke depan akan menyusul Pulau Sulawesi dan Papua) cenderung beresiko mengalami kualitas udara yang buruk dibandingkan wilayah lain yang tidak dijadikan areal masif perkebunan sawit. Secara spasial kebijakan yang mempermudah pembukaan lahan besar untuk perkebunan industri menempatkan Sumatera dan Kalimantan menjadi tidak menguntungkan bagi penghuninya. Ada relasi antara kebijakan tata ruang dengan menempatkan perkebunan besar tanaman industri di pulau-pulau tidak padat penduduk dengan potensi ketidakadilan lingkungan secara geografis (Jessup, 2014). Indonesia juga telah melakukan pencemaran udara lintas negara khususnya bagi negaranegara tetangga seperti Malaysia, Singapura, Thailand, Philipina dan Brunei Darussalam.

\section{Gerakan Keadilan Lingkungan}

Upaya penanggulangan kabut asap ternyata tidak cukup hanya mengandalkan kesigapan aparat, penegakan hukum, pembenahan kebijakan pemerintah dengan ditetapkannya Penundaan Pemberian Izin Baru dan Penyempurnaan Tata Kelola di Hutan Alam Primer dan Gambut sebagaimana diatur dalam Inpres No. 8/2015, akan tetapi juga keterlibatan semua pemangku kepentingan. Peran serta masyarakat masih terbatas pada tataran respon saat bencana. Masyarakat belum secara intens terlibat dalam pencegahan dan pemantauannya. Bahkan pemerintah dan masyarakat cenderung lupa pernah ada bencana asap seketika musim hujan tiba.

Salah satu gagasan keadilan lingkungan adalah pengakuan terhadap berbagai aktoraktor terkait (relevant actors) dengan persoalan penggunaan lahan untuk tanaman industri seperti sawit. Pemerintah cenderung lupa melibatkan pemilik lahan, masyarakat adat di 
sekitar hutan dan lembaga swadaya masyarakat terkait, ketika menetapkan kebijakan menyangkut lahan. Sebenarnya sejak dini kelompok-kelompok relevan ini sudah dapat dipetakan termasuk diprediksi kerugian dan resiko yang akan mereka alami dari aktifitas lingkungan. Pengakuan terhadap mereka harus dimulai sejak dini bukan pada saat teridentifikasi sebagai korban saja.

Dalam banyak kasus lingkungan memang pengalaman menjadi korban telah mendorong kelompok relevan membentuk gerakan lingkungan untuk menggugat hak atas lingkungan yang baik dan sehat sampai pada upaya-upaya mempengaruhi kebijakan nasional. Lihatlah contoh bagaimana tragedi Love Canal di Niagara Fall, Amerika Serikat pada tahun 1974 menjadi titik awal gerakan lingkungan yang melahirkan peraturan perlindungan lingkungan (Environmental Protection Act) yang adil di tingkat negara bagian dan Federal Amerika Serikat. Perubahan undang-undang lingkungan menjadi gerakan akar rumput (bottom-up) dari masyarakat bukan semata-mata lahir karena tuntutan penguasa.

Pengalaman dan kesadaran bencana kabut asap seharusnya menjadi momentum memunculkan gerakan keadilan lingkungan. Gerakan ini bermaksud untuk menyelamatkan manusia dan hutan melalui cara mempengaruhi berbagai kebijakan yang selama ini lebih berpihak pada industri kelapa sawit atau perkebunan industri lainnya. Indonesia membutuhkan munculnya gerakan lingkungan yang mampu mengubah sikap personal, kelompok dan bahkan lebih luas yaitu komitmen negara.

Pengalaman menyadari sebagai pihak yang menerima resiko dan menjadi korban adalah tahap awal memahami hak lingkungan yang baik dan sehat. Kesadaran dapat pula berangkat dari pengalaman bahwa negara telah gagal melindungi pemenuhan hak atas lingkungan yang baik dan sehat. Berbagai kesadaran seperti ini mampu mendorong masyarakat melakukan resistensi terhadap kebijakan bahkan membentuk gerakan budaya, moral dan politik (Cable dan Benson, 1993) untuk melindungi hak lingkungannya.

Masyarakat dapat juga membentuk institusi lokal yang melibatkan masyarakat adat atau komunitas peduli yang mempunyai kewenangan me-restrukturisasi kelompok sosial untuk tujuan melindungi ekosistem hutan untuk menjamin tersedianya udara yang baik dan sehat. Institusi ini dapat membentuk penjaga lahan dan bersinergi dengan jagawana yang dimiliki oleh Perhutani untuk melakukan kontrol sosial terhadap lahan.

Memang untuk membentuk kontrol sosial, masyarakat harus kuat dalam segala hal. Misalnya, mereka (masyarakat adat dan kelompok masyarakat lokal lainnya) harus diakui otonomi nya di wilayah lahan. Otonomi di wilayah lahan digambarkan dengan berbagai cara misalnya adanya pengakuan hak individu maupun komunitas atas lahan, adanya pengakuan atas komunitas lokal, adanya pengakuan hak asasi manusia (baik hak ekonomi, sosial dan budaya). Senyatanya terkait dengan perkebunan sawit, hak-hak mereka sebagai individu dan kelompok secara perlahan tak dihormati. Mereka dimiskinkan dengan jalan pengalihan hak atas lahan individu maupun adat menjadi lahan industri sawit. Mereka dimiskinkan dengan jalan bekerja sebagai petani kebun dan buruh perusahaan. Mereka bukan petani yang bebas dan mandiri. Hak mereka dilanggar dengan tereduksinya hak atas lingkungan yang sehat dan baik. Sumber air mereka tercemar dengan residu pupuk tanaman industri. Mereka dimiskinkan karena sumber pangan yang berasal dari hutan perlahan lenyap sejalan dengan bergantinya hutan menjadi lahan tanaman industri. Hal lain yang paling masif adalah terancamnya hak mereka atas kesehatan dan lingkungan yang baik dengan tercemarnya udara dengan asap (The Institute for Ecosoc Rights, 2015). 
Melalui gerakan keadilan lingkungan, masyarakat dapat melakukan perubahan yang berarti dengan membentuk ketahanan hutan baik dalam konteks lokal, regional dan nasional. Hal ini termasuk pula upaya mempengaruhi regulasi perlindungan lahan dan hutan. Masyarakat dapat membentuk gerakan dengan misi penghentian ijin membuka lahan untuk tanaman industri. Secara personal dan berkelompok ada gerakan anti produksi perusahaan pembakar lahan yang dilakukan di Singapura yaitu dengan tidak membeli produk-produk mereka.

\section{PENUTUP SIMPULAN}

Carut marut penanganan kebakaran hutan membuktikan bahwa kebijakan pemerintah saja tidak cukup untuk mengurai dan menyelesaikan persoalan ini. Keterlibatan masyarakat melalui gerakan keadilan lingkungan tampaknya menjadi penting digagas untuk mengakhiri persoalan kebakaran hutan yang sepertinya jalan di tempat. Sudah saatnya masyarakat bergerak untuk lingkungan yang lebih baik. Kita berharap semua pihak dapat belajar dari bencana ini. Sudah saatnya pengalaman ini menggugah kesadaran semua pihak untuk bersikap dan beraksi melindungi hutan guna menjamin hak lingkungan manusia tidak hanya di wilayah-wilayah terdampak tapi juga di Indonesia, negara-negara jiran dan untuk semua mahluk di alam semesta.

\section{DAFTAR PUSTAKA}

Cable and Benson, 1993, Acting Locally: Environmental justice and the emergence of grassroots Environment Organization, Social Problem, Vol 40, No 4, November 1993. pp. $464-477$

Food and Agriculture Organization for The United Nation, 2015, Global Forrest Resource Assessment, 2015

Jessup, B., 2014, Environmental Justice as Spatial and Scalar Justice: A Regional Waste Facility or a Local Rubbish Dump Out of Place? McGill International Journal of Sustainable Development Law and Policy, Vol. 9, No.2, 2014, p: 69-107

The Institute for Ecosoc Rights, 2015, Industri Perkebunan Sawit dan Hak Asasi Manusia: Potret Pelaksanaan Tanggung Jawab Pemerintah dan Korporasi terhadap Hak Asasi Manusia di Kalimantan Tengah, Jakarta: The Institute for Ecosoc Rights

United Church of Christ Commision for Racial Justice, 1987, Toxic wastes and race: a national report on the racial and socioeconomic characteristics of communities with hazardous waste sites, New York, United Church of Christ.

Walker, G., 2012, Environmental Justice: Concepts, Evidence and Politics, London and New York, Routledge

\section{Media}

Harian Kompas, 14 September 2015

Harian Kompas, 15 September 2015

Harian Kompas, 13 Nopember 2015

Harian Kompas, 16 Maret 2020 